\title{
Dynamics regulating major trends in Barents Sea temperatures and subsequent effect on remotely sensed particulate inorganic carbon
}

\author{
Erlend Kjeldsberg Hovland ${ }^{1, *}$, Heidi M. Dierssen ${ }^{1,2}$, Ana Sofia Ferreira ${ }^{3}$, \\ Geir Johnsen ${ }^{1,4}$ \\ ${ }^{1}$ Trondhjem Biological Station, Department of Biology, Norwegian University of Science and Technology, \\ 7491 Trondheim, Norway \\ ${ }^{2}$ University of Connecticut, Department of Marine Sciences/Geography, Groton, Connecticut 06340, USA \\ ${ }^{3}$ National Institute of Aquatic Resources, Charlottenlund Slot Jægersborg Allé 1, 2920 Charlottenlund, Denmark \\ ${ }^{4}$ University Centre in Svalbard, PO Box 156, Longyearbyen 9171, Norway
}

\begin{abstract}
A more comprehensive understanding of how ocean temperatures influence coccolithophorid production of particulate inorganic carbon (PIC) will make it easier to constrain the effect of ocean acidification in the future. We studied the effect of temperature on Emiliania huxleyi PIC production in the Barents Sea using ocean colour remote sensing data. Gross annual PIC production was calculated for 1998-2011 from SeaWiFS and MODIS data and coupled with results from previous studies to create a time-series from 1979-2011. Using that data, we investigated (1) correlations between various climate indices, models and temperature recordings of the Kola transect, and (2) the dynamics of temperature and PIC production. A strong inverse correlation $\left(r^{2}=0.88\right)$ was found between the strength of the North Atlantic subpolar gyre (SPG) with a $3 \mathrm{yr}$ lead and major trends in temperatures from the Kola transect. The effect of ocean temperature on PIC production was complex but generally positive, explaining roughly $50 \%$ of the annual variability and indicating that rising temperatures in the North Atlantic may favour coccolithophorid PIC production in the Barents Sea. Positive phases of the Atlantic multidecadal oscillation tended to precede PIC blooms by 1 yr.
\end{abstract}

KEY WORDS: Subpolar gyre - Barents Sea $\cdot$ Temperature effect $\cdot$ Atlantic multidecadal oscillation $\cdot$ Calcification $\cdot$ Coccolithophorid $\cdot$ Remote sensing

\section{INTRODUCTION}

Coccolithophorids (Haptophyta) are responsible for a major part of calcium carbonate formation in the global ocean through the production of coccoliths and are at the centre of ongoing discussions regarding ecological impacts of ocean acidification (Feely et al. 2004, Beaufort et al. 2007, Balch \& Utgoff 2009, Doney et al. 2009). Coccoliths elevate the albedo of the sea and are quantifiable as particulate inorganic carbon (PIC) through ocean colour remote sensing (Balch et al. 2005).
The coccolithophorid Emiliania huxleyi (Lohmann) appears to have advanced into the sub-Arctic Bering and Barents Seas during the last 3 decades and has established annual bloom events in both areas (Merico et al. 2003, Smyth et al. 2004, Sukhanova et al. 2004, Hovland et al. 2013). Enhanced stratification, low nutrient availability and relatively high irradiance are considered important inducing conditions for $E$. huxleyi blooms (Nanninga \& Tyrrell 1996, IglesiasRodríguez et al. 2002, Tyrrell \& Merico 2004). However, it is still not possible to model the actual non-bloom to bloom transitions in a realistic manner 
(Merico et al. 2004). In the case of the Bering Sea, the appearance of E. huxleyi blooms was connected to the El Niño event in 1997, with a particularly shallow mixed layer depth (MLD) and resulting high sea surface temperature (SST) $3-4^{\circ} \mathrm{C}$ above normal (Vance et al. 1998, but see Merico et al. 2003). Studies have yet to discover similar connections between the $E$. huxleyi bloom occurrence in the Barents Sea and large-scale climate forces in the Atlantic.

There is a strong link between atmospheric forcing and variations in ocean circulation. The subpolar gyre (SPG) has been used as a proxy of ocean current systems in the North Atlantic from altimetry data (Häkkinen 2001, Häkkinen \& Rhines 2004). Here, sea surface height (SSH) is used to reflect changes in both heat storage (Häkkinen \& Rhines 2004, Hátún et al. 2005) and water buoyancy (Larsen et al. 2012). The main forcing mechanisms behind the strength of the SPG are the wind stress curl (WSC) and heat flux (Holliday 2003, Böning et al. 2006). The strength of the gyre, which is inversely related to the 'gyre in-

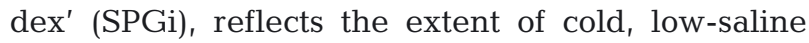
waters within the North Atlantic, and how these waters will influence the North Atlantic Current (NAC) (Hátún et al. 2009b). A weak gyre (high index values) means warmer, high-saline conditions, whereas a strong gyre is responsible for an eastwards shift of cold, low-salinity waters over the Rockall Plateau (Hátún et al. 2009a). Thus, this pool of water affects the TS (temperature and salinity) structure of the NAC (Hátún et al. 2005, 2009a, Hátún \& Gaard 2010), and the Norwegian Atlantic Current (NwAC) (Loeng 1991). Due to upstream oceanic advection and heat exchange, pronounced or extreme TS anomalies are usually found in the Fram Strait with a lag of 3-4 yr, depending on the speed of the Atlantic water flow (Holliday et al. 2008, Lohmann et al. 2009b).

Besides the impact in the Nordic Seas, the SPG strength may also be related to deep water formation, thereby impacting the thermohaline circulation (THC) (Böning et al. 2006, Lohmann et al. 2009a, 2009b) and the Atlantic multidecadal oscillation (AMO) (Hátún et al. 2009b). The AMO, coined by Kerr (2000), describes long-term oscillations (65$75 \mathrm{yr}$ ) in the average North Atlantic SST, and its phases have profound effects on the ecosystem of the western hemisphere (Enfield et al. 2001, Knight et al. 2006, Hodson et al. 2010). It is strongly influenced by the TS properties of the inflow waters to the Nordic Seas (Holliday et al. 2008, Lohmann et al. 2009b), which, together with the Labrador/Irminger Sea, are the main sources of North Atlantic deep water
(NADW) (Hansen \& Østerhus 2000, Hansen et al. 2008). Thus, a weak atmospheric forcing (weak SPG, high SPGi) is linked to positive TS anomalies, which may then be expected in the Barents Sea 3-4 yr later (Holliday et al. 2008).

The North Atlantic Oscillation (NAO) has also been associated with the strength of the SPG, as both are influenced by the WSC and water buoyancy (Häkkinen \& Rhines 2004). NAO is defined as the sea level pressure (SLP) between the Icelandic low and the Azores high; thus, in a negative NAO phase $\left(\mathrm{NAO}^{-}\right)$, one may observe a weakening of the SPG (Holliday 2003, Lohmann et al. 2009a). The major weakening of the SPG in the mid-1990s has been linked to a $\mathrm{NAO}^{-}$, as blocked westerly winds led to a warm, more saline subpolar ocean (Häkkinen et al. 2011). Since both are influenced by the westerly winds (Visbeck et al. 1998, Hátún et al. 2009a, Häkkinen et al. 2011), the 2 indices are expected to have similar patterns. As Häkkinen \& Rhines (2004) suggested, a positive NAO $\left(\mathrm{NAO}^{+}\right)$leads to an anticyclonic circulation of the WSC; thus, an anticlockwise circulation that characterizes the SPG. In addition, NAO, which is used to represent the atmospheric forcing in the North Atlantic (Häkkinen \& Rhines 2004), has also been linked to the Barents Sea climate variability, due to a strong correlation with Atlantic water influx through the Barents Sea Opening (BSO) over the last $30 \mathrm{yr}$ (Sandø et al. 2010).

Increased heat transport via Atlantic water through the BSO will, along with solar heating, mediate thermal stratification of the upper ocean in the region (Loeng \& Drinkwater 2007), thereby reducing the upwelling of nutrients - a phenomenon shown to correlate strongly with coccolithophorid bloom occurrence (Tyrrell \& Merico 2004). In this sense, the term 'bloom' is often used to characterize waters with more than $1 \times 10^{9}$ Emiliania huxleyi cells $\mathrm{m}^{-3}$ (Tyrrell $\&$ Merico 2004). Note, however, that ratios of coccoliths to E. huxleyi cells in the North Atlantic have been reported from 10 to 4000 coccoliths cell ${ }^{-1}$, demonstrating that detached coccoliths normally represent the bulk PIC in the water column (Van der Wal et al. 1995, Balch et al. 1996, Smyth et al. 2002).

In the bloom phase of Emiliania huxleyi, PIC concentrations may not correlate with chlorophyll $a$ (chl a), so using PIC as a proxy for E. huxleyi biomass should be done with caution (Van Bleijswijk et al. 1994, Volent et al. 2011, Hovland et al. 2013). Therefore, the expression 'bloom' in this paper is used as a biogeochemical term referring to bulk PIC from coccoliths rather than phytoplankton biomass. We will not discuss chl a data here since remote sensing algo- 

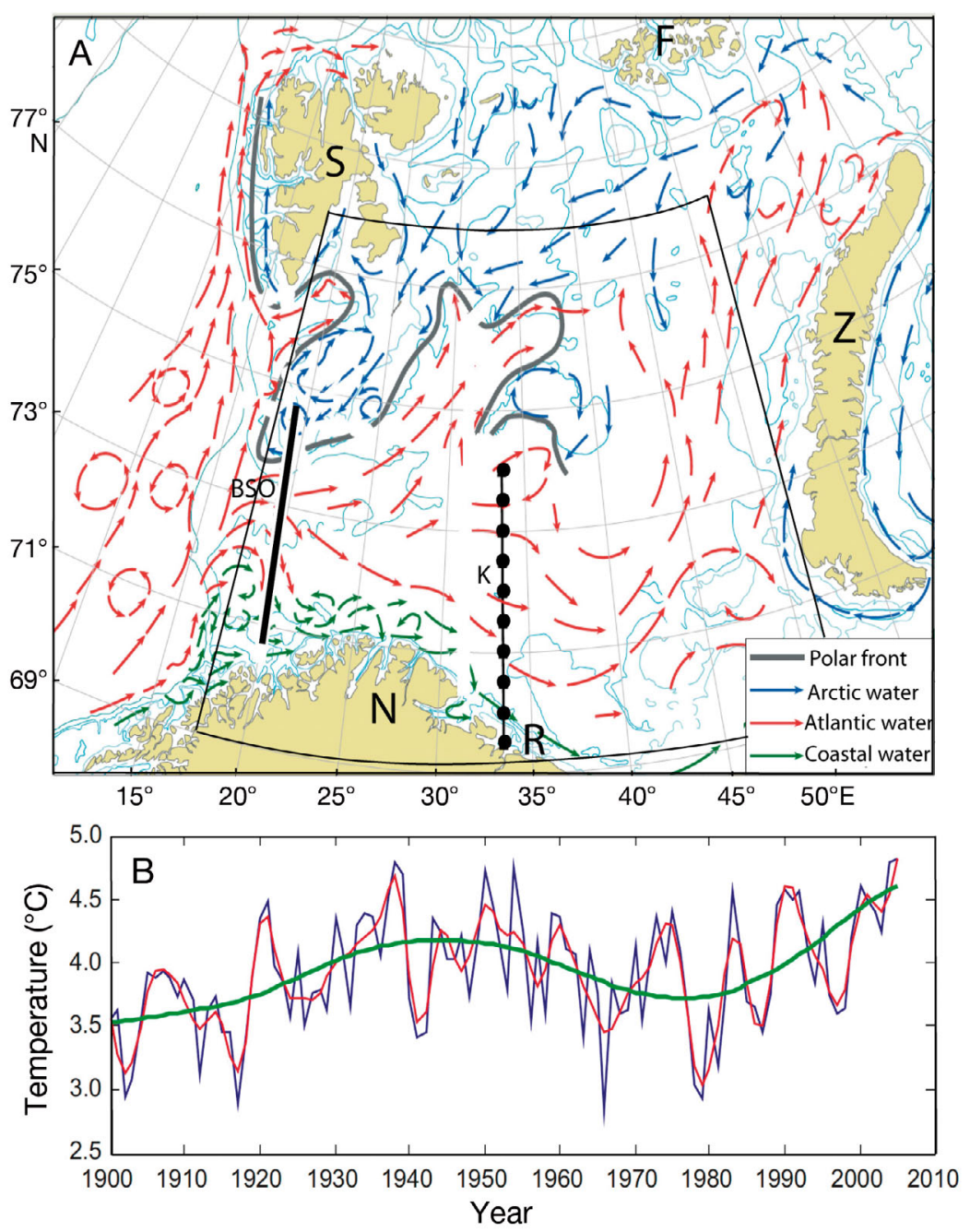

Fig. 1. (A) The Barents Sea with the Norwegian coast (N), Russian coast (R), Svalbard archipelago (S), Novaya Zemlya (Z) and Franz Josef Land (F). Barents Sea opening (BSO) and Kola transect (K) lines. The region of interest (ROI) used in this study is outlined in black. Mean position of the polar front in a relatively warm year as well as current patterns for Arctic, Atlantic, and coastal waters are shown. Modified from Sunnanå et al. (2009) by permission. (B) Mean temperature from the Kola transect (0-200 m depth) shown as a blue line. Red and green lines show the corresponding 5 and $30 \mathrm{yr}$ low pass filtering curves, respectively. The time-series shows apparent climate fluctuations in quasi-periodic cycles from years to several decades. Data courtesy of PINRO. Modified from Ingvaldsen \& Loeng (2009) by permission

rithms retrieve chl a poorly in coccolith-dominated waters with high reflectance and low chlorophyll (Balch et al. 2005).

This study has 3 main objectives: (1) to evaluate different approaches of measuring or predicting ocean temperatures in the southern Barents Sea, (2) to evaluate bloom dynamics of PIC in the Barents Sea from ocean colour remote sensing imagery, and (3) to determine the effect of ocean temperature on the PIC production of Emiliania huxleyi blooms in this area. Our main hypothesis is that a weakening of the SPG will lead to advection of warmer and more saline waters to the Barents Sea with a 3-4 yr lag time and that this will positively affect PIC production.

\section{MATERIALS AND METHODS}

\section{Study area}

The Barents Sea (Fig. 1A) is a shallow, continental shelf sea covering $\sim 1.5 \times$ $10^{6} \mathrm{~km}^{2}$. It is bordered by the Svalbard Archipelago in the northwest, the coast of Finnmark and the Kola peninsula in south, Franz Josef Land in the northeast, and Novaya Zemlya in the east. Warmer North Atlantic water flows in mainly through the BSO, and is separated from the colder Arctic water by the polar front (Loeng 1991). The region of interest (ROI) used to subset the satellite data in this study covered all PIC blooms in the Barents Sea east of the $\mathrm{BSO}$, and was operationally defined by $69-78^{\circ} \mathrm{N}$ and $18-52^{\circ} \mathrm{E}$, an ocean area of $4.3 \times 10^{5} \mathrm{~km}^{2}$ (Fig. 1A). A good overview of the general physical properties of the ROI during the relevant Emiliania huxleyi-driven PIC bloom months (June through September) can be found in Panteleev et al. (2006).

Annual mean ocean temperature from the Kola transect shows a variability of $\sim 2^{\circ} \mathrm{C}$ since the 1900 s and a potential longterm natural periodicity of high and low temperature evident over roughly $70 \mathrm{yr}$ (Fig. 1B). There has been a positive trend in the mean temperatures in the Barents Sea since the advent of ocean colour satellites used in this study (1979 to 2011), but temperatures may enter a cooling phase in the future following the multi-decadal oscillations observed in the Kola Transect data (see 'Discussion').

\section{Data collection}

Satellite-derived data on PIC were retrieved from the Sea-viewing Wide Field-of-view Sensor (SeaWiFS) and Moderate Resolution Imaging Spectro- 
radiometer (MODIS) on satellite Aqua from the Oceancolor website (oceancolor.gsfc.nasa.gov, accessed 15 Jan 2012) as 8 d (weekly) and 30 d (monthly) averaged data. Monthly SST data from the advanced very high resolution radiometer (AVHRR) were downloaded via the PO.DAAC website (podaac.jpl.nasa. gov, accessed 15 Jan 2012) and MODIS SST data from Oceancolor Web. MODIS data (2002-2011) were supplemented with SeaWiFS data to create a time-series from 1998 through 2011. SSTs from MODIS were supplemented with AVHRR data in the same fashion. All data were mapped to $9 \mathrm{~km}$ resolution.

The SPGi used in this study has been published by Hátún \& Gaard (2010) and Larsen et al. (2012) and is based on an empirical orthogonal function (EOF; Preisendorfer 1988) created by Häkkinen \& Rhines (2004) from gridded SSH data. Here, we used a time-series of the gyre index from 1993 to 2011, as in Larsen et al. (2012), because these are physical data based on sea height. There is an extended, modelled time-series of this gyre index (Hátún et al. 2005) that we chose not to use because this introduced unknown errors. However, the linear trend of the modelled time-series was calculated in order to detrend the shorter one.

The AMO index is created from a subset of the Kaplan extended V2 model of global, detrended SST, simulated from 1856 until present (Reynolds \& Smith 1994, Kaplan et al. 1998). We also retrieved monthly averaged SST anomalies in the southern Barents Sea extracted from the Kaplan dataset, constrained to our ROI and downloaded from the IRI/LDEO Climate Data Library (iridl.ldeo.columbia.edu, accessed 23 Jun 2012).

Time series of the summer open water index (SOWI) and ocean stratification strengths were taken from the dataset of Johannesen et al. (2012). The SOWI is a quantitative, area-based measure of the variation in the summer ice-free area north of $79^{\circ} \mathrm{N}$ and is an indicator of the area experiencing seasonal ice melt in the Barents Sea.

The record of various climatic indices from 1951 to 2011, including Arctic oscillation (AO), NAO and $\mathrm{AMO}$, were retrieved as monthly values from Earth System Research Laboratory (www.esrl.noaa.gov, accessed 10 Jun 2012). Records of ocean temperature and salinity anomalies (TA and SA, respectively) from the Russian Kola meridian transect (Fig. 1) were provided by the Polar Research Institute of Marine Fisheries and Oceanography (PINRO, Murmansk). Both annual and summer (June through August) data, averaged over the upper $200 \mathrm{~m}$ of Stns 3-7 $\left(70^{\circ} 30^{\prime} \mathrm{N}-72^{\circ} 30^{\prime} \mathrm{N}\right)$ were analyzed after linear detrending of the time-series.

\section{Ocean temperatures}

The various approaches and indices to measure SST and ocean temperature in the Barents Sea were tested for significant correlations $(p<0.05)$. Linear correlations are employed throughout this study. Temporal leads of 1-4 yr for AMO and SPGi were also tested, shown as subscript $t-x$, where $x$ is the lead time in years.

\section{Bloom threshold}

Counts of Emiliania huxleyi cells from water samples were performed at the Flødevigen marine station by the Institute of Marine Research (IMR, Bergen) in 2005, and the Norwegian Component of the Ecosystem Studies of Subarctic and Arctic Regions (NESSAR) project in 2007, by means of light microscopy as described in Hovland et al. (2013). Satellite-derived PIC values were extracted from the weekly scene that contained data closest in time and location to the corresponding cell count, whereupon the bloom threshold of PIC was calculated by linear regression forced through the origin. Additionally, we calculated an average satellite summer background value from the Sargasso Sea in 4 randomly selected years for comparison before applying the threshold as the bloom definition to the satellite data.

\section{Bloom development}

Satellite images from the Barents Sea are often affected by cloud cover (Hovland et al. 2013), and this was the case especially for the northern part of the ROI. To account for this, and to avoid the error that would result from variable coverage from week to week, we used a 'composite' procedure where missing data pixels in a scene were filled in with the value from the week before. This introduced an unquantifiable error that should still be less than assuming no PIC underneath a cloud covered pixel. For all satellite data calculations, pixel values were multiplied by the cosine of the latitude to calculate an area-weighted mean for the region. Since PIC is logarithmically distributed, geometric mean was employed for these calculations. The weekly standing stocks of PIC were calculated assuming a uniform vertical distribution from the surface to $15 \mathrm{~m}$ depth (Hovland et al. 2013). 


\section{PIC production}

Gross annual bloom production of PIC was calculated assuming a $1 \mathrm{wk}$ turnover time for calcite (Buitenhuis et al. 2001) and a weekly calcite sedimentation rate of 0.21 (Van der Wal et al. 1995). The calculations were based on scenes from 25 June through 11 September (day of the year 177 to 256 , Weeks 1-10). The weekly standing stocks of PIC were thus simply multiplied by 1.21 and summed for each year. After Week 10, low solar altitude prohibited retrieval of ocean colour data from the ROI. SST values were also calculated from monthly scenes, using arithmetic means of the ROI. In order to investigate for a potential coupling between ocean temperature dynamics and the PIC production in the Barents Sea, we compared MODIS data on SST with the corresponding PIC value for each pixel in monthly scenes of the bloom peak month of August from 2002 to 2011.

\section{Extended PIC record}

An extended PIC record of remotely sensed Emiliania huxleyi blooms in the Barents Sea was constructed as follows: For years 1979 to 1986, bloom PIC production was set to 0 , based on a study of the Coastal Zone Color Scanner (CZCS) mission (Brown \& Yoder 1994). Smyth et al. (2004) note, however, that only 87 scenes were available over the Barents Sea for the entire mission, so blooms could have occurred in this period. AVHRR observations of E. huxleyi blooms in the Barents Sea for the years 1987 to 1997 were visually quantified by the apparent relative size of the blooms in images from Smyth et al. (2004). The approach was confirmed by visually checking that the monthly averaged bloom area in the AVHRR images in years 1998 to 2002 corresponded in size to the monthly PIC image from overlapping MODIS and SeaWiFS scenes. Finally, annual PIC production was taken from the present data set for the years 1998 to 2011, and the AVHRR observations were scaled accordingly. We applied this pseudo-quantitative approach because quantitative inter-satellite comparison and ground truthing of reflectance in the Barents Sea was beyond the scope of this study. The climatic indices and ocean temperature datasets were tested for correlations with the extended PIC record, in order to uncover indices capable of describing the variability in PIC.

\section{RESULTS}

\section{Ocean temperatures}

Of the correlations between indices and temperatures, the most striking feature was a very robust correlation $\left(\mathrm{r}^{2}=0.87\right)$ between the detrended, annual Kola TA and the gyre index with a 3 yr lead $\left(\mathrm{SPGi}_{t-3}\right.$, Table 1, Fig. 2) over the last 2 decades. Lead times of 2 and 4 yr yielded $\mathrm{r}^{2}$ values of only 0.48 and 0.42 , respectively. Kola TA for a given year could be estimated with the relation: Kola TA $=0.59+1.91 \times$ $\mathrm{SPGi}_{t-3}$.

The $\mathrm{SPGi}_{t-3}$ had the lead time with the strongest correlation of both remotely sensed SST and Kaplan SSTA for the Barents Sea with an $\mathrm{r}^{2}$ of $\sim 0.5$. Similar strength of correlation was observed between the instantaneous AMO and SPGi. Somewhat ambiguous to the $3 \mathrm{yr}$ lead, Kola TA displayed almost identical correlation strength with both $\mathrm{AMO}_{t-2}$ and $\mathrm{AMO}_{t-3}$, but the $\mathrm{r}^{2}$ of these ( 0.23) were much lower than that with the $\mathrm{SPGi}_{t-3}$ (Table 1). $\mathrm{SPGi}_{t-3}$ also correlated positively with SOWI $\left(\mathrm{r}^{2}=0.39, \mathrm{p}=0.018\right.$, $\mathrm{n}=14$ ).

Kola TA correlated significantly with SST, with the Kaplan SSTA dataset having a slightly higher $\mathrm{r}^{2}$ than that of the remotely sensed SST (Table 1). Between them, the Kaplan dataset and the remotely sensed SST displayed a fairly robust correlation of $\mathrm{r}^{2}=0.64$. Kola SA displayed significant but very weak correlation with $\mathrm{AMO}_{t-2}$ and $\mathrm{AMO}_{t-3}$, as well as a stronger correlation with remotely sensed SST (Table 1).

NAO yielded only one significant result: a negative correlation with AMO $\left(\mathrm{r}^{2}=0.20, \mathrm{p}<0.001, \mathrm{n}=61\right)$. AO displayed some significant, albeit very weak, correlations with Kola TA (positive), AMO (negative) and Kaplan SSTA (positive). $\mathrm{r}^{2}$ was $<0.16$ for all 3; $\mathrm{p}<0.03$ and $\mathrm{n}=61$.

\section{Bloom threshold}

Different thresholds and algorithms have been used to characterize blooms of coccolithophores and PIC (e.g. Gordon \& Balch 1999, Smyth et al. 2004, Moore et al. 2012). The PIC and cell concentrations are often uncoupled because PIC can be present in the form of detached coccoliths long after Emiliania huxleyi has disappeared from the water column. To allow for comparisons with past studies, we analyzed the relationship between PIC and E. huxleyi cells for this region in order to estimate the threshold value of PIC which corresponded to $1 \times 10^{9}$ cells $\mathrm{m}^{-3}$. The $E$. 
Table 1. Linear correlation strength $\left(\mathrm{r}^{2}\right)$, significance $(\mathrm{p})$ and number of observations $(\mathrm{n})$ between annual indices and environmental variables in the Barents Sea. Sea surface temperature (SST) anomaly from the Kaplan V2 model (Kaplan SSTA) pertains to the region of interest (ROI) of this paper and is extracted from the same model as the Atlantic multidecadal oscillation (AMO). SST and particulate inorganic carbon (PIC) is based on ocean colour data for the same ROI, but PIC production includes previously published data. SPGi is an index inversely related to the strength of the North Atlantic subpolar gyre, and subscript $t-x$ denotes a lead time of $x$ years. Kola TA and SA stands for temperature and salinity anomalies from the Kola transect. ns: not significant

\begin{tabular}{|c|c|c|c|c|c|c|}
\hline & $\begin{array}{c}\text { PIC } \\
\text { production } \\
(1979-2011)\end{array}$ & $\begin{array}{c}\text { Kola } \\
\text { TA } \\
(1951-2011)\end{array}$ & $\begin{array}{c}\text { Remote } \\
\text { SST } \\
(1998-2011)\end{array}$ & $\begin{array}{c}\text { Kaplan } \\
\text { SSTA } \\
(1951-2011)\end{array}$ & $\begin{array}{c}\mathrm{AMO}_{t-3} \\
(1951-2011)\end{array}$ & $\begin{array}{c}\text { Kola } \\
\text { SA } \\
(1951-2011)\end{array}$ \\
\hline \multicolumn{7}{|c|}{$\mathrm{SPGi}_{t-3}(1993-2011)$} \\
\hline$r^{2}$ & $\mathrm{~ns}$ & 0.87 & 0.48 & 0.5 & 0.51 & ns \\
\hline $\mathrm{p}$ & 16 & $<0.001$ & 0.006 & 0.002 & $<0.001$ & 16 \\
\hline $\mathrm{n}$ & & 16 & 14 & 16 & 19 & \\
\hline \multicolumn{7}{|c|}{$\mathrm{AMO}_{t-2}(1951-2011)$} \\
\hline $\mathrm{r}^{2}$ & 0.41 & 0.26 & 0.39 & 0.1 & 0.52 & 0.09 \\
\hline $\mathrm{p}$ & $<0.001$ & $<0.001$ & 0.018 & 0.014 & $<0.001$ & 0.021 \\
\hline $\mathrm{n}$ & 33 & 61 & 14 & 61 & 61 & 61 \\
\hline \multicolumn{7}{|c|}{$\mathrm{AMO}_{t-3}(1951-2011)$} \\
\hline$r^{2}$ & 0.49 & 0.23 & ns & 0.11 & & 0.1 \\
\hline $\mathrm{p}$ & $<0.001$ & 0.001 & 14 & 0.008 & & 0.014 \\
\hline $\mathrm{n}$ & 33 & 14 & & 61 & & 61 \\
\hline \multicolumn{7}{|c|}{ PIC production } \\
\hline$r^{2}$ & & 0.31 & ns & 0.46 & 0.49 & 0.15 \\
\hline $\mathrm{p}$ & & 0.001 & 14 & $<0.001$ & $<0.001$ & 0.027 \\
\hline $\mathrm{n}$ & & 33 & & 33 & 33 & 33 \\
\hline \multicolumn{7}{|c|}{ Kola TA (1951-2011) } \\
\hline$r^{2}$ & & & 0.51 & 0.57 & 0.23 & ns \\
\hline $\mathrm{p}$ & & & 0.004 & $<0.001$ & $<0.001$ & 61 \\
\hline $\mathrm{n}$ & & & 14 & 61 & 61 & \\
\hline \multicolumn{7}{|c|}{ RemoteSST } \\
\hline$r^{2}$ & & & & 0.64 & ns & 0.42 \\
\hline $\mathrm{p}$ & & & & $<0.001$ & 14 & 0.012 \\
\hline $\mathrm{n}$ & & & & 14 & & 14 \\
\hline
\end{tabular}

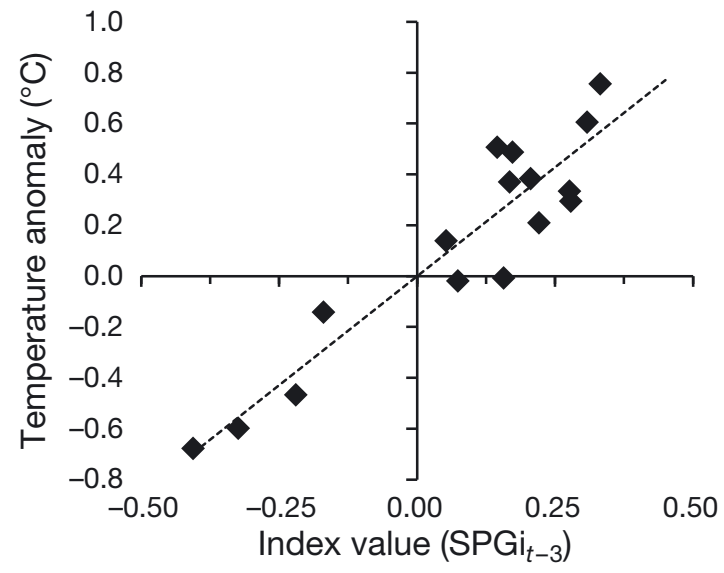

Fig. 2. Annual Barents Sea temperature anomalies, as a function of the strength of the subpolar gyre with a 3 yr lead $\left(\mathrm{SPGi}_{t-3}\right)$. The temperatures are measured in the Kola meridian transect and the SPGi is based on remotely sensed sea surface height where high values indicate a relatively warm and weak gyre. The dashed line is the linear best fit, with

$$
r^{2}=0.87
$$

huxleyi cell counts and satellite PIC correlated poorly $\left(\mathrm{r}^{2}=0.17\right)$, but with a significant positive trend that yielded a bloom PIC threshold value of roughly $4 \mathrm{mmol} \mathrm{C} \mathrm{m}^{-3}$ corresponding to $1 \times 10^{9}$ cells $\mathrm{m}^{-3}$ (Fig. 3). Although less conservative than some other coccolithophorid bloom classification schemes (Gordon \& Balch 1999, Moore et al. 2012), this threshold captured the surface extent of conspicuous PIC levels in the region (Fig. 4) and yielded bloom extents comparable to Smyth et al. (2004). The threshold value was also more than an order of magnitude higher than the background PIC values from the oligotrophic waters of the Sargasso Sea, which varied between 0.16 and $0.20 \mathrm{C} \mathrm{mmol} \mathrm{m}^{-3}(\mathrm{n}=4)$.

\section{Bloom development}

The 'composite' method of filling gaps due to cloud cover by retaining pixels from previous scenes yiel- 


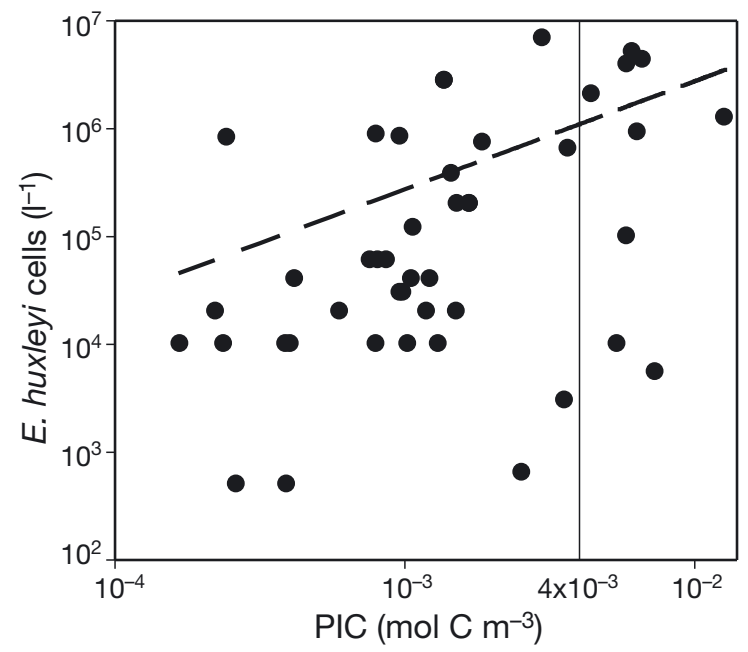

Fig. 3. Cell counts of Emiliania huxleyi from the Barents Sea in 2005 and 2007, plotted on log scales against corresponding remotely sensed particulate inorganic carbon (PIC). Dashed black line is the linear correlation (slope $=276 \times$ $10^{6} \mathrm{PIC}, \mathrm{r}^{2}=0.17, \mathrm{p}=0.006$ ) forced through origin, and the dropline marks the bloom threshold PIC value that corresponded to $1 \times 10^{9}$ cells $\mathrm{m}^{-3}$

ded realistic and coherent bloom images (Fig. 4); a comparison of weekly estimates calculated with and without this method is shown in Fig. 5. PIC blooms that started developing in the first or second week following 26 June reached their peak PIC standing stocks $4-5$ wk later, expanding rapidly (Fig. 6). Several years displayed comparatively delayed bloom expansion (1998-2000, 2006 and 2009-2010), with peak concentrations occurring in Weeks 7-10. These 'late bloomers' peaked the lowest of the recorded years in question (Fig. 6). At the peak weeks for all years, the ROI contained between 0.2 and $0.8 \mathrm{Tg}$ $\left(1 \mathrm{Tg}=10^{12} \mathrm{~g}\right) \mathrm{PIC}$, and blooms were estimated at $70000-322000 \mathrm{~km}^{2}$.

For all weeks (Weeks 1-10) in the data set the average $( \pm \mathrm{SD})$ cloud cover was $0.47 \pm 21 \%$, mostly dominating over the northern, less PIC-influenced part of the ROI. By Week 10, clouds and low solar angle severely hampered satellite data retrieval with an average cloud cover of $62 \pm 22 \%$, but Week 9 still displayed bloom areas up to $200000 \mathrm{~km}^{2}$ (Fig. 6).

Blooms always started to develop within the ROI, and no patches of blooms were observed to drift into the Barents Sea from the Norwegian Sea. The area of initiation varied from 20 to $37^{\circ} \mathrm{E}$ and from the coast of Finnmark in the south to $75^{\circ} \mathrm{N}$. The blooms never occurred north of the polar front, which approximately follows the $5^{\circ} \mathrm{C}$ surface temperature isoterm, consistent with Burenkov et al. (2011).

\section{PIC production}

From 1998 through 2011, the gross annual calcite production of the PIC blooms varied from 0.48 to $1.59 \mathrm{Tg} \mathrm{C} \mathrm{yr}^{-1}$ within the ROI. Production was relatively low from 1998-2001 with a sudden increase to the highest production in 2001, after which a negative trend was observed before another increase occurred in 2011 (Table 2). Annual production from our records alone (1998-2011) yielded no significant correlations with the temperature data or climate indices investigated here, so we focus on results from the historic PIC records.

PIC production correlated significantly with the maximal bloom area attained each year $\left(r^{2}=0.81\right.$, $\mathrm{p}<0.001)$. The annual PIC production in the Barents Sea deviated substantially from the dynamics of published coccolithophorid bloom areas in the Northern Hemisphere, which displayed a marked peak in 1998, followed by significantly lower and less variable bloom areas (Moore et al. 2012). A study using SeaWiFS data on backscattered light $\left(b_{\mathrm{b}}\right)$ as a proxy for PIC concentrations in the Barents Sea obtained dynamics comparable to ours, as their annual mean $b_{\mathrm{b}}$ and our PIC production values correlated well $\left(\mathrm{r}^{2}=\right.$ 0.86, $\mathrm{p}<0.001$ ) for 1998-2007 (Burenkov et al. 2011).

\section{SST vs. PIC}

PIC as a function of SST displayed several general properties for all August months concerned (20022011; Fig. 7A): The major part of the data was concentrated around the intercept PIC $=0.3 \mathrm{mmol} \mathrm{C} \mathrm{m}^{-3}$ and $\mathrm{SST}=4^{\circ} \mathrm{C}$, and at the lower end of the PIC range (below PIC $=1 \mathrm{mmol} \mathrm{C} \mathrm{m}^{-3}$ ), PIC increased slightly with SST. There was a minimum in observations of bloom pixels, i.e. above the threshold of $4 \mathrm{mmol} \mathrm{C} \mathrm{m}^{-3}$, around $4^{\circ} \mathrm{C}$. From $5^{\circ} \mathrm{C}$, bloom pixel observations increased sharply with SST toward the peak in PIC values centred around $8^{\circ} \mathrm{C}$. As SST increased from 8 to $12^{\circ} \mathrm{C}$, maximal PIC values declined. In addition, each year displayed some distinctive patterns of PIC as a function of SST, and the years 2006, 2007 and 2011 had prominent peaks of PIC values at different SSTs (Fig. 7B). These years had the highest noted PIC values, but this was not necessarily reflected in highest gross PIC production (Table 2).

Fig. 8 shows satellite imagery from August of a relatively warm year with high PIC production (2007) and a cold one with low production (2010). The SST images (Fig. 8A,B) show that the $5^{\circ} \mathrm{C}$ isotherm approximately followed the polar front and that this shifted 

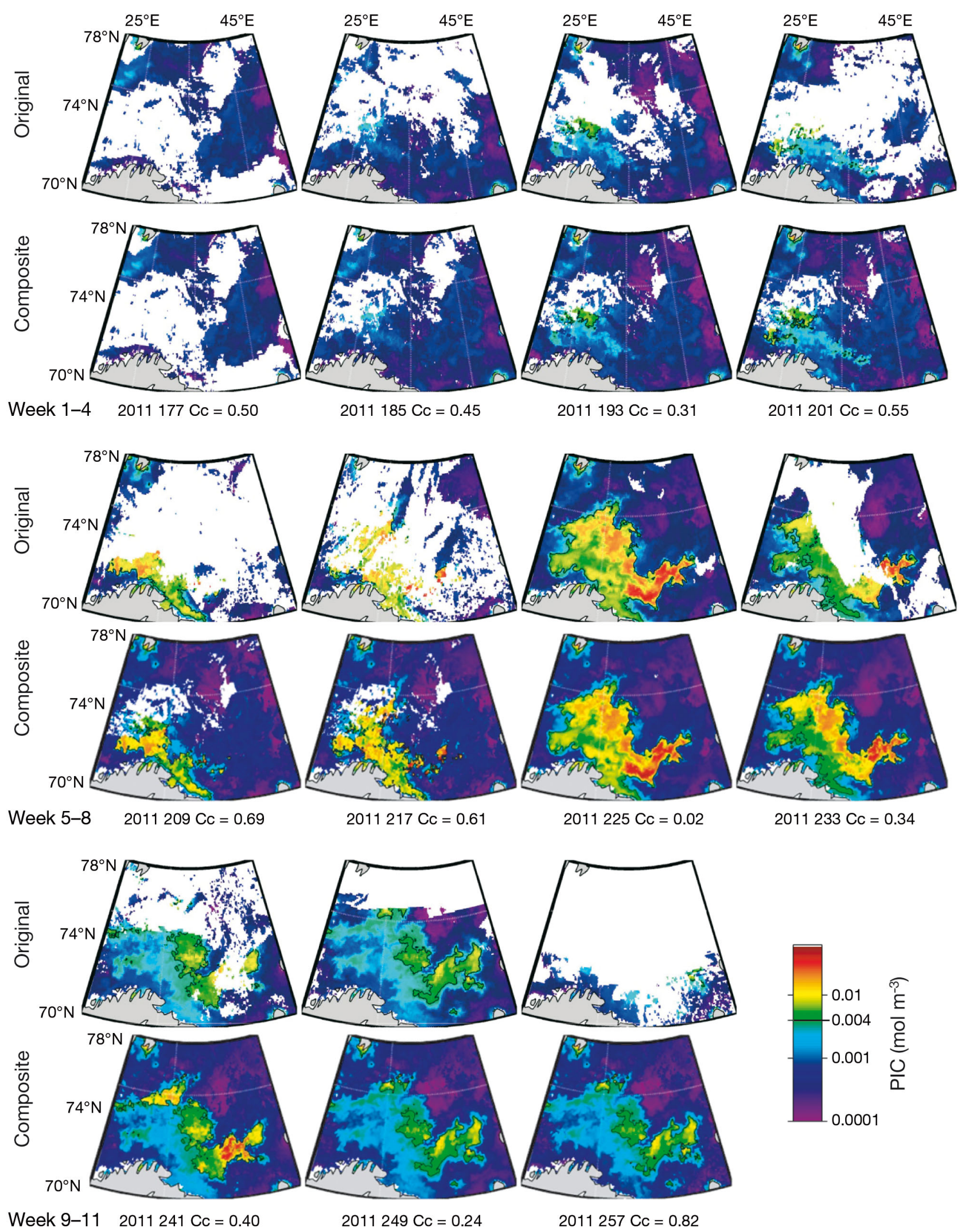

Fig. 4. Weekly time-series of the Emiliania huxleyi-driven particulate inorganic carbon (PIC) bloom in 2011. Solid black line at $0.004 \mathrm{~mol} \mathrm{C} \mathrm{m}^{-3}$ (see key) represents the threshold PIC corresponding to $1 \times 10^{9} \mathrm{cells} \mathrm{m}^{-3}$. Row 'original' is compared to the 'composite' technique below it, where a given pixel value is retained from the previous week when the new value is invalid due to cloud cover or insufficient available light (white). Cc: fraction of total cloud cover for each scene. Starting day of the year is noted under each scene; Week 1 starts on Day 177 (26 Jun) and Week 11 ends on Day 264 (21 Sep) 

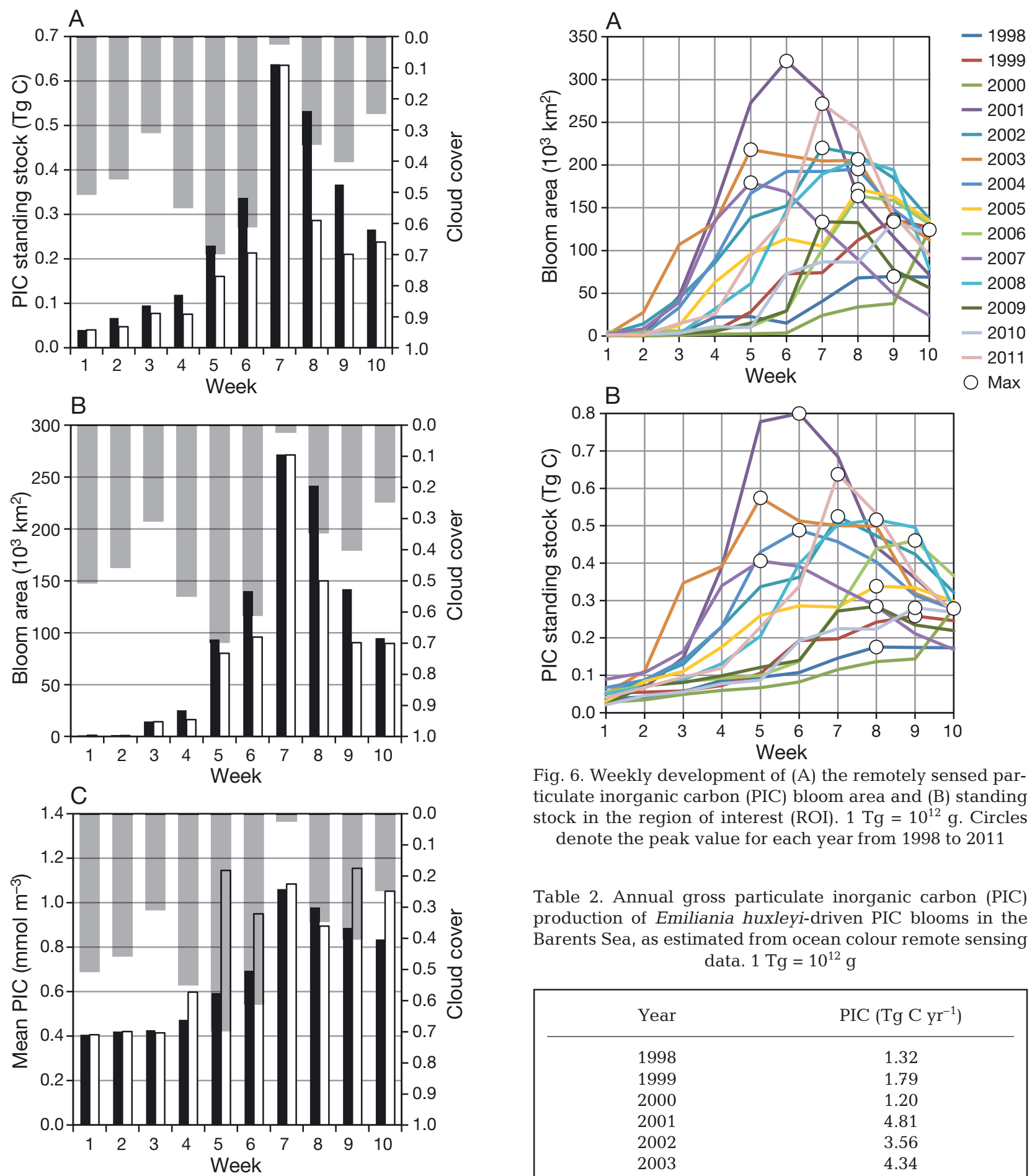

Fig. 6. Weekly development of (A) the remotely sensed particulate inorganic carbon (PIC) bloom area and (B) standing stock in the region of interest (ROI). $1 \mathrm{Tg}=10^{12} \mathrm{~g}$. Circles denote the peak value for each year from 1998 to 2011

Table 2. Annual gross particulate inorganic carbon (PIC) production of Emiliania huxleyi-driven PIC blooms in the Barents Sea, as estimated from ocean colour remote sensing data. $1 \mathrm{Tg}=10^{12} \mathrm{~g}$

Fig. 5. Comparison of calculations with the original remotely sensed particulate inorganic carbon (PIC) time-series, shown as black bars, and calculations with the composite technique, as white bars, for Weeks 1-10 of 2011. Grey bars show total cloud cover fraction on a reverse axis. (A) Total standing stock of PIC in the region of interest (ROI). $1 \mathrm{Tg}=10^{12} \mathrm{~g}$. (B) Area defined by the PIC bloom threshold. (C) Geometric mean of PIC. All pixels were area-

\begin{tabular}{|c|c|}
\hline Year & $\operatorname{PIC}\left(\mathrm{Tg} C \mathrm{yr}^{-1}\right)$ \\
\hline 1998 & 1.32 \\
\hline 1999 & 1.79 \\
\hline 2000 & 1.20 \\
\hline 2001 & 4.81 \\
\hline 2002 & 3.56 \\
\hline 2003 & 4.34 \\
\hline 2004 & 3.50 \\
\hline 2005 & 2.66 \\
\hline 2006 & 2.52 \\
\hline 2007 & 3.02 \\
\hline 2008 & 3.31 \\
\hline 2009 & 1.87 \\
\hline 2010 & 1.79 \\
\hline 2011 & 3.26 \\
\hline Mean \pm SD & $2.78 \pm 1.78$ \\
\hline
\end{tabular}



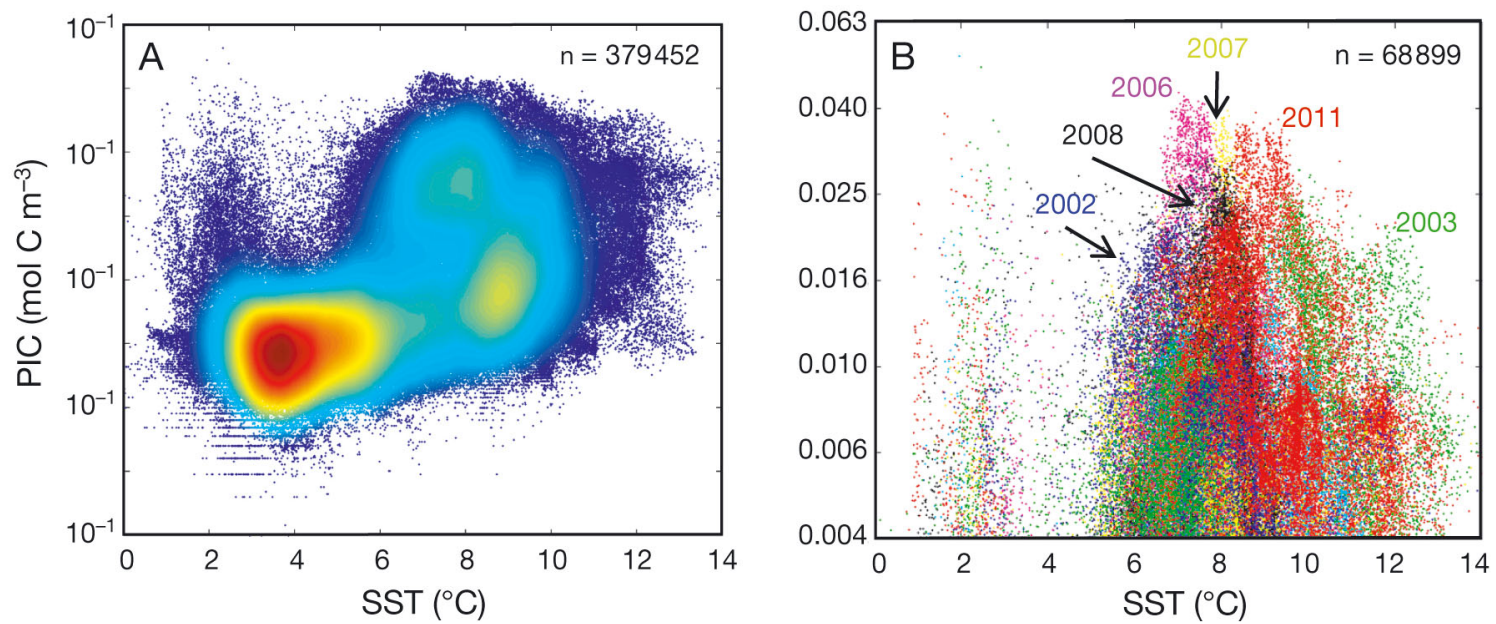

Fig. 7. Semi-log plot of remotely sensed sea surface temperature (SST) vs. particulate inorganic carbon (PIC) pixel values in the region of interest (ROI) of the Barents Sea for averaged August months in the years 1998-2011. (A) Colour-density plot where red $=$ higher density of observations (n). The data indicate a positive trend and a marked increase in high PIC values above $4.5^{\circ} \mathrm{C} \mathrm{SST}$. High PIC values observed below $4^{\circ} \mathrm{C}$, that is, the left part of the 'saddle' shape, are presumed non-coccoliths

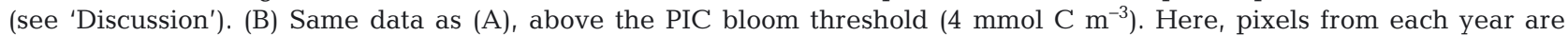
coloured differently, and the most prominent years are given in the figure. Note the peak in PIC around $8^{\circ} \mathrm{C} \mathrm{SST}$

considerably from one year to the other, consistent with Ellingsen et al. (2008) and Skagseth et al. (2011). August 2007 displayed a deeply eastwards penetration of warm, Atlantic waters visible as an area with $>10^{\circ} \mathrm{C}$ near Novaya Zemlya in the east; the bulk of the PIC bloom also shifted eastwards compared to the cold year. In 2007, the bloom stretched across a wide range of isotherms from 5 to $10^{\circ} \mathrm{C}$, while in 2010 the bloom followed the isotherms more closely from 5 to $8^{\circ} \mathrm{C}$.

For both example years, it would seem that the 'tail' of high PIC values around SST $=2^{\circ} \mathrm{C}$ (Fig. 8E,F) stemmed from bloom pixels surrounding the island Edgeøya in the northwest of the ROI. This envelope of PIC could easily have originated from terrestrial run-off or resuspended material in the shallow waters around the island and was therefore not considered further in this paper. Other possible sources of high reflectance such as resuspended diatom frustrules (Merico et al. 2003) have not been observed in the Barents Sea, and resuspension of sediments was unlikely since deep mixing in the region is uncommon in the summer (Sakshaug et al. 2009).

\section{Extended PIC record}

Interestingly, positive linear correlation was observed between the extended PIC production timeseries (1979-2011) and the instantaneous SPGi $\left(\mathrm{r}^{2}=\right.$ $0.40, \mathrm{p}=0.004, \mathrm{n}=19$ ), but not with $\mathrm{SPGi}_{t-3}$ (Table 1). However, the extended PIC record was found to correlate positively with the annual average of the
Kola TA, $\mathrm{AMO}_{t-3}$ and the ROI-based Kaplan SSTA (Table 1). In addition, the PIC record correlated with the stratification index for the southwest Barents Sea $\left(\mathrm{r}^{2}=0.31, \mathrm{p}=0.001, \mathrm{n}=31\right)$, taken from Johannesen et al. (2012). There were otherwise no significant correlations between PIC production and the mean annual or seasonal remotely sensed SST.

Neither instantaneous nor leading NAO values from any period of time (annual or seasonal) yielded significant correlation with the extended PIC record. Significant negative correlation was observed between the extended PIC record and a 2 yr leading El Niño southern oscillation $\left(\mathrm{ENSO}_{t-2}\right)$, and with pacific decadal oscillation (PDO) indices leading at 0-2 yr. However, these correlations were weak $\left(\mathrm{r}^{2}<0.24\right)$ and will not be considered further here.

A pattern emerged when viewing key variables as a time-series, where the Emiliania huxleyi-driven PIC blooms were preceded by positive AMO index values by 1 yr (Fig. 9). Moreover, the increase and concurrent disappearance of PIC blooms from 1988 to 1994 followed the pattern of the AMO, as well as the reappearance and continuous record of blooms following the positive AMO phase from 1997 to 2011.

\section{DISCUSSION}

\section{Barents Sea TS variability}

During the period between 1993 and 2011, the $\mathrm{SPGi}_{t-3}$ was found to be among the strongest pub- 

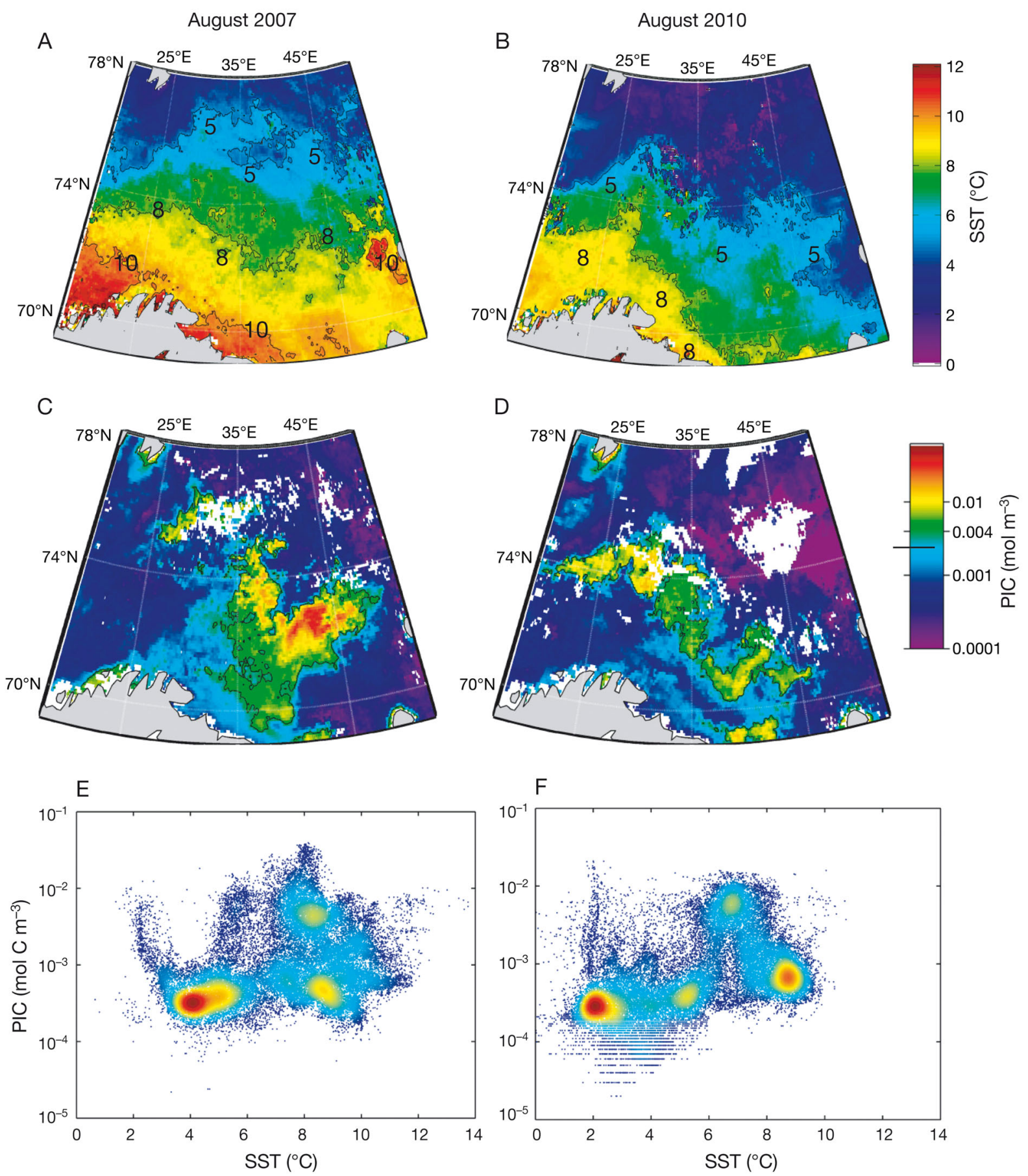

Fig. 8. Comparison of remotely sensed particulate inorganic carbon (PIC) and sea surface temperature (SST) averaged over August in a relatively warm year (2007: A, C \& E) and cold year (2010: B, D \& F) in the Barents Sea. (A) and (B) show SST with isotherms at 5,8 and $10^{\circ} \mathrm{C}$. Note that averaged temperatures did not exceed $10^{\circ} \mathrm{C}$ in the cold year and that the low Atlantic water intrusion caused a southward shift of the polar front, presumed to correspond to the $5^{\circ} \mathrm{C}$ isotherm. (C) and (D) show PIC values, while (E) and (F) show SST vs. PIC data in the same manner as Fig. 7A

lished predictors of Barents Sea temperatures (Ottersen et al. 2000, Ottersen \& Stenseth 2001, Sandø et al. 2010) and could possibly be used as a simple and relatively accurate forecast for Kola transect temperatures 3 yr in advance, together with potential effects on the ecosystem. The temporal consistency of this correlation beyond the 2 investigated decades remains to be proven, and the influence of dynamics such as the NAO on Barents Sea heat content have been shown to change over time (e.g. Sandø et al. 


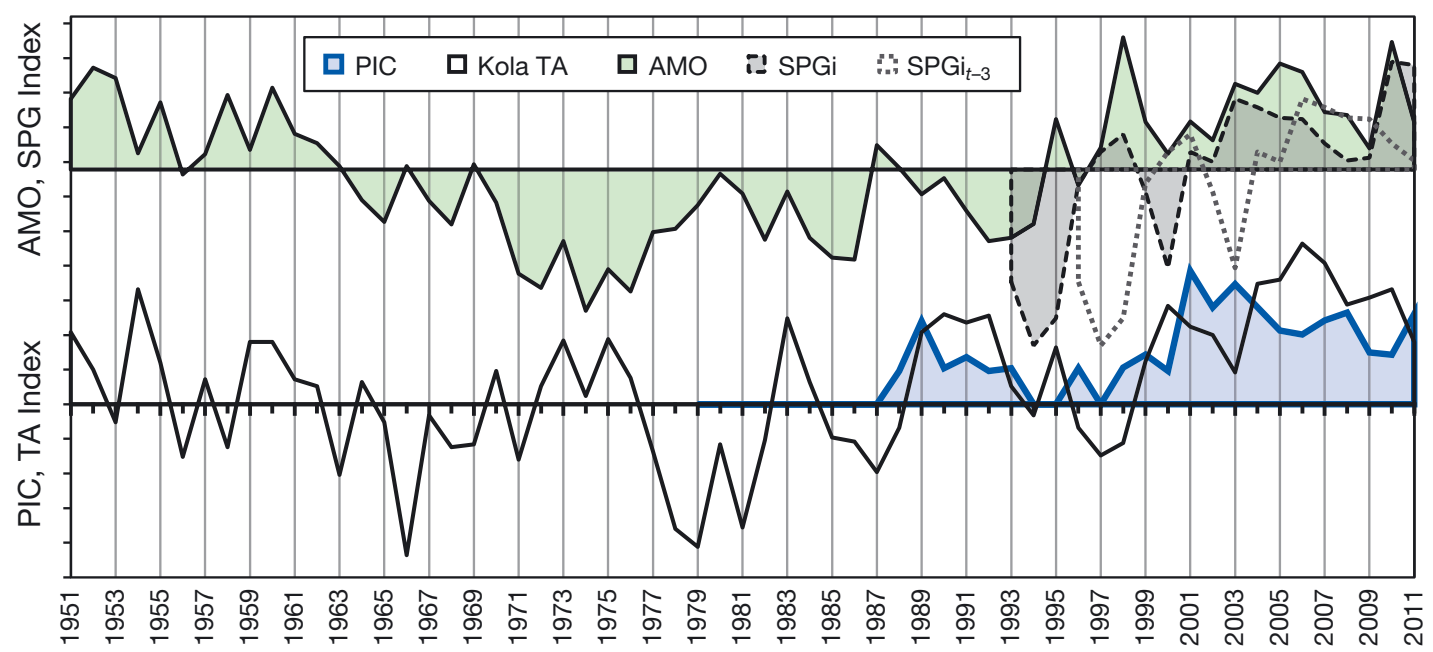

Fig. 9. Time-series of particulate inorganic carbon (PIC) production and key indices in the Barents Sea from 1951 to 2011, on relative scales. PIC production is shown in blue and is based on present and previously published remote sensing data from 1979 to 2011. The black line is the Kola temperature anomaly (TA), and the green-filled area is Atlantic multidecadal oscillation (AMO). The dashed line is the subpolar gyre index (SPGi), and the dotted, grey line is the SPGi with a 3 yr lag. Note the similarity in shape of the latter and the Kola TA, as well as the AMO and the PIC production. Given the 3 yr lag, the high SPGi values of 2010 and 2011 may translate into record high temperatures in the Barents Sea in 2013

2010). In light of this, the results from time-series correlations of different lengths must be interpreted with caution.

The 3 yr lag between the SPGi and major trends in Kola TA suggests a link through advection; tracing back the major currents entering the Barents Sea would place the origin around the Faroe-Shetland channel (Belkin 2004, Holliday et al. 2008). There was a significant correlation between the AMO and the SPGi, suggesting that the positive AMO phases are currently heating and weakening the SPG. This is consistent with our main hypothesis that the SPG is related to the flow of warmer waters into the NwAC. Note that the correlation between the SPGi and the Kola TA was much stronger than with the AMO (Table 1). However, the Kola SA displayed no such connection, even though correlations have been found in other studies (Holliday et al. 2008, Skagseth et al. 2008). Alternatively, the TAs 3 yr upstream of the Kola TA could be due to air-sea heat-fluxes regulated by forces simultaneously and independently setting up the strength of the SPG. If these forces were linked to the NAO/AO, affecting the gyre region and the Barents Sea at the same time, this may explain that the SPGi correlations had a 3 yr lead on Kola TA but none on PIC production. Even though the NAO and AO indices did not display any atmospheric pattern connection between the gyre region and the Barents Sea in our data set, using a single number as an indicator for the atmospheric patterns over half a hemisphere cannot capture all aspects of the system (e.g. Sandø et al. 2010). More problematic to this alternative explanation is the added lag time before the effect of modelled NAO and wind stress is observed in the SPG strength, around 1 and $6 \mathrm{yr}$, respectively (Langehaug et al. 2012). All in all, direct regulation of major trends in Barents Sea temperature is suggested to occur due to the dynamics of the SPG. A number of other factors in the coupled atmosphere-ocean system may also affect Barents Sea temperature, so our results still require confirmation through modelling and continued time-series observations in the future.

A phase change in SA at the BSO around 2002 coincided with a lasting weakening of the SPG (Hátún et al. 2005, Holliday et al. 2008). This indicates that even though salinities from the Kola transect were not directly correlated with the $\mathrm{SPGi}_{t-3}$, the Barents Sea salinity is still affected by the gyre dynamics on a large scale. In 2010, the gyre again weakened substantially (Fig. 9), and the effect of this weakening may manifest itself in 2013-2014 as the highest temperatures recorded in the Kola transect since 1900 (Figs. $1 \&$ 9).

AMO represents the heat anomaly of the North Atlantic SST, thus including the area covered by the SPG. Increased heat content increases the sea height and this is the reflected in the correlation between the AMO and the SPGi. Our results corroborate previous studies demonstrating the influence of the AMO on the Barents Sea (e.g. Skagseth et al. 2008). Correlation between the AMO and Kola SA was very 
weak (Table 2), as would be expected since the AMO represents over-arching temperature oscillations in the entire North Atlantic that are not directly linked to Atlantic water flow.

Some models indicate that the Barents Sea will experience continued warming over the next 60$80 \mathrm{yr}$ (Ellingsen et al. 2008, Philippart et al. 2011). On the other hand, the apparent amplitude of $\sim 70 \mathrm{yr}$ cycles in the AMO and Kola transect (Fig. 1B) predict a decrease in ocean temperatures of roughly $0.5^{\circ} \mathrm{C}$ over the next $\sim 35 \mathrm{yr}$, corroborated by Boitsov et al. (2012). This may potentially negate global warming for a while, until the oscillation swings again and creates a double warming effect.

TS variability and PIC production

A positive phase of the AMO index preceded known bloom occurrences in the Barents Sea by 1-2 yr (Brown \& Yoder 1994, Smyth et al. 2004; our Fig. 9). It is particularly important that this index may explain the observed disappearance of Emiliania huxleyi-driven PIC blooms in the years 1994-1997 and the reappearance in 1998. Note that bloom observations in years prior to 1987 are not yet proven as true negatives. All in all, these are strong indications that PIC blooms have not been prominent in the Barents Sea since the last positive AMO phase 7 decades ago. Sediment record studies, such as Iglesias-Rodríguez et al. (2008), could probably shed some light on this.

Smyth et al. (2004) indicated that bloom occurrence might be associated with anomalies of negative salinity coupled with positive temperature in the Barents Sea. However, positive anomalies of both salinity and temperature have been observed at the BSO since around 2002 (Skagseth et al. 2008), and of the 2 variables, temperature is known to dominate stratification in the region (K. Drinkwater pers. comm.). A shallow mixed layer depth of $<30 \mathrm{~m}$ is robustly correlated with Emiliania huxleyi blooms (Nanninga \& Tyrrell 1996, Tyrrell \& Merico 2004), which points towards a relationship between the positive TA and blooms of PIC in the Barents Sea. Additionally, bloom occurrence coincided strongly with years of positive TA (Fig. 9). The results from the extended PIC timeseries indicate that ocean temperatures may explain $30-50 \%$ of the variation in the PIC production in the Barents Sea, with the Kaplan SSTA being the most successful. The different methods for measuring temperature utilized in this study are very different by nature, however. The Kola TA is from a relatively deep upper layer compared to the others, whereas the remotely sensed SST is very shallow, and the Kaplan data are based on modelling. The lack of correlation between PIC production and remote SST could be due to the shortness of this time-series.

Note that temperature alone does not completely explain the Emiliania huxleyi bloom occurrence or PIC production in the Barents Sea. PIC values as a function of SST from remote sensing showed complicated patterns, where the origin (Atlantic or coastal water) and hydrographical properties of the water masses may be important. In particular, the strength of thermal stratification is governed by gradients in the water column rather than absolute values, and this may play a critical role. As demonstrated above, there was as expected a significant correlation between stratification in the SW Barents Sea and PIC production.

A more indirect and supplementary explanation to the PIC-temperature connection is the positive correlation between zooplankton biomass and BSO Atlantic water influx: With an increase in copepod abundance, increased grazing on larger phytoplankton such as diatoms may favour calcite-forming coccolithophorids and small flagellates (Rey 2004, Ellingsen et al. 2008, Dalpadado et al. 2012). This, along with other ecological control mechanisms, is likely important in explaining the variability in PIC production that temperature cannot account for.

\section{PIC bloom properties}

Using the 'composite' technique of retaining pixel values produced credible results. Under supervision, even with its inherent limitations, the technique was a good approach to estimate bloom areas and PIC production. Recent studies have estimated global calcification at 1.6 Pg PIC $\mathrm{yr}^{-1}\left(1 \mathrm{Pg}=10^{15} \mathrm{~g}\right)$ through remote sensing of ocean colour (Balch et al. 2007) and 1.1 Pg PIC $\mathrm{yr}^{-1}$ through carbonate chemistry (Feely et al. 2004). From Fig. 6 in Balch et al. (2007), an average value of PIC production of roughly $5 \mathrm{mg}$ PIC m $\mathrm{m}^{-3} \mathrm{~d}^{-1}$ seemed realistic from June through September (122 d) in our ROI. Again assuming an average depth of production at $15 \mathrm{~m}$, the calcite production in their study would then total 3.9 Tg PIC in the ROI for 2002, which was comparable to our result of $3.6 \mathrm{Tg}$ PIC the same year (Table 2). Annual PIC production in our study area stood for only $0.1-0.3 \%$ of the global estimate of Balch et al. (2007). Still, this implies that in 1998-2011, the PIC production in the southern Barents Sea varied between 0.6 and 2.5 times that of the 
global average per $\mathrm{km}^{2}$. Compared to estimates of annual primary production in the entire Barents Sea of $82 \mathrm{Tg} \mathrm{C} \mathrm{yr}^{-1}$ (Le Fouest et al. 2011) to $136 \mathrm{Tg} \mathrm{C} \mathrm{yr}^{-1}$ (Sakshaug 2004), PIC production in this study corresponded to $0.01-0.06 \%$. Even if these numbers are comparatively small, biological precipitation of PIC through calcification and the subsequent fate of PIC affects the regional carbonate chemistry and sequestration budget (Rost \& Riebesell 2004) and has an adverse effects on the potential primary production within the PIC blooms (Hovland et al. 2013).

No bloom patches were seen to drift into the Barents Sea but started forming within different parts of the southern region from year to year, for which there might be 3 possible explanations: (1) There is a local seeding stock specific to the region, or that seeding populations drift into the Barents Sea via either (2) Atlantic water from the NwAC or (3) coastal currents. Combinations of these might be possible, and the matter could be elucidated with genetic sampling and comparison of local Emiliania huxleyi stocks with pelagic North Atlantic and Norwegian coastal water stocks.

\section{CONCLUSIONS AND OUTLOOK}

We conclude that current trends in Barents Sea ocean temperatures, as measured in the Kola transect, are related to the strength of the SPG. The sea surface height-based gyre index $\left(\mathrm{SPGi}_{t-3}\right)$ provides good prediction for major trends in Barents Sea temperatures $3 \mathrm{yr}$ in advance. Accordingly, significantly elevated temperatures are expected for 2013-2014. The apparently contradicting results between some published temperature models and the AMO/Kola transect cycle in the Barents Sea show the importance of long-term data series where such cycles are discernible. Studies focused on the presently demonstrated SPG-Barents Sea connection are needed in order to elucidate if it will remain consistent in the future.

Temperatures from the Kola transect and the ROIbased Kaplan SSTA and the AMO have been shown to have a significant effect on the PIC production in the Barents Sea. Moreover, as our extended PIC record follows the apparent AMO cycle pattern, we predict a discontinuation of the Emiliania huxleyidriven PIC blooms in the Barents Sea within a $30 \mathrm{yr}$ period. Ocean acidification is expected to negatively affect coccolithophorids, complicating the prediction of $E$. huxleyi performance in the future (Riebesell et al. 2009, Beaufort et al. 2011). This is an important task to solve, as blooms of E. huxleyi have profound effects on the carbon budget (e.g. Balch et al. 2005, Hutchins 2011) and on Arctic ecosystems in general, as found in studies from the Bering Sea (Vance et al. 1998, Sukhanova et al. 2004). The long-term effects of ocean acidification are only discernible from satellite time-series on the scale of several decades (Henson et al. 2010), underlining the need for continued development of satellite remote sensing programs.

With the control of PIC production in the Barents Sea in mind, further investigations on temperature, water mixing and stratification, current fluxes, wind patterns, light regimes and ecological control (e.g. grazing and nutrient consumption) are needed to constrain the effect of ocean acidification. For instance, if the Barents Sea PIC blooms were to disappear as this study predicts, ocean acidification could easily (and perhaps erroneously) be named the culprit without rigorous understanding of other influential factors such as ocean temperature.

Acknowledgements. We thank L. J. Naustvoll and M. R. Kleiven at Flødevigen for performing the cell counts. Thanks are also due PINRO for kindly providing temperature and salinity data from the Kola transect. The constructive feedback from Dr. H. Hátún and 2 anonymous reviewers helped to greatly improve this paper. This work was initiated through a grant from Det Kongelige Norske Videnskabers Selskap (DKNVS, Trondheim), and finished under the strategic program 'Marine Coastal Development' at NTNU. Funding for A.S.F. was provided by the Norden Toplevel Research Initiative sub-programme 'Effect Studies and Adaptation to Climate Change' through the Nordic Centre Centre for Research on Marine Ecosystems and Resources under Climate Change (NorMER). Funding for H.M.D. was provided by the U.S. Office of Naval Research and US National Aeronautics and Space Administration's Ocean Biology and Biogeochemistry Program.

\section{LITERATURE CITED}

Balch WM, Utgoff PE (2009) Potential interactions among ocean acidification, coccolithophores, and the optical properties of sea water. Oceanography 22:146-159

Balch WM, Kilpatrick KA, Trees CC (1996) The 1991 coccolithophore bloom in the central North Atlantic. 1. Optical properties and factors affecting their distribution. Limnol Oceanogr 41:1669-1683

> Balch WM, Gordon HR, Bowler BC, Drapeau DT, Booth ES (2005) Calcium carbonate measurements in the surface global ocean based on Moderate-Resolution Imaging Spectroradiometer data. J Geophys Res 110:C07001, doi: 10.1029/2004JC002560

> Balch W, Drapeau D, Bowler B, Booth E (2007) Prediction of pelagic calcification rates using satellite measurements. Deep-Sea Res II 54:478-495

Beaufort L, Probert I, Buchet N (2007) Effects of acidification and primary production on coccolith weight: implications 
for carbonate transfer from the surface to the deep ocean. Geochem Geophys Geosyst 8:Q08011, doi: 10.1029/2006 GC001493

Beaufort L, Probert I, de Garidel-Thoron T, Bendif EM and others (2011) Sensitivity of coccolithophores to carbonate chemistry and ocean acidification. Nature 476:80-83

Belkin IM (2004) Propagation of the 'Great Salinity Anomaly' of the 1990s around the northern North Atlantic. Geophys Res Lett 31:L08306, doi: 10.1029/2009GL019334

> Boitsov VD, Karsakov AL, Trofimov AG (2012) Atlantic water temperature and climate in the Barents Sea, 2000-2009. ICES J Mar Sci 69:833-840

> Böning CW, Scheinert M, Dengg J, Biastoch A, Funk A (2006) Decadal variability of subpolar gyre transport and its reverberation in the North Atlantic overturning. Geophys Res Lett 33:L21S01, doi: 10.1029/2006GL026906

- Brown CW, Yoder JA (1994) Coccolithophorid blooms in the global ocean. J Geophys Res 99:7467-7485

Buitenhuis ET, van der Wal P, de Baar HJW (2001) Blooms of Emiliania huxleyi are sinks of atmospheric carbon dioxide: a field and mesocosm study derived simulation. Global Biogeochem Cycles 15:577-587

> Burenkov VI, Kopelevich OV, Rat'kova TN, Sheberstov SV (2011) Satellite observations of the coccolithophorid bloom in the Barents Sea. Oceanology 51:766-774

> Dalpadado P, Ingvaldsen RB, Stige LC, Bogstad B, Knutsen T, Ottersen G, Ellertsen B (2012) Climate effects on Barents Sea ecosystem dynamics. ICES J Mar Sci 69: 1303-1316

> Doney SC, Balch WM, Fabry VJ, Feely RA (2009) Ocean acidification: a critical emerging problem for the ocean sciences. Oceanography 22:16-25

> Ellingsen IH, Dalpadado P, Slagstad D, Loeng H (2008) Impact of climatic change on the biological production in the Barents Sea. Clim Chang 87:155-175

- Enfield DB, Mestas-Nunez AM, Trimble PJ (2001) The Atlantic multidecadal oscillation and its relation to rainfall and river flows in the continental US. Geophys Res Lett 28:2077-2080

Feely RA, Sabine CL, Lee K, Berelson W, Kleypas J, Fabry VJ, Millero FJ (2004) Impact of anthropogenic $\mathrm{CO}_{2}$ on the $\mathrm{CaCO}_{3}$ system in the oceans. Science 305:362-366

Gordon HR, Balch WM (1999) MODIS detached coccolith concentration. In: Algorithm theoretical basis document. NASA. NASA's Earth Observing System. ATBD-MOD23. Ver. 4. http://eospso.gsfc.nasa.gov/sites/default/files/ atbd/atbd_mod23.pdf

Häkkinen S (2001) Variability in sea surface height: a qualitative measure for the meridional overturning in the North Atlantic. J Geophys Res 106:13837-13848

> Häkkinen S, Rhines PB (2004) Decline of subpolar North Atlantic circulation during the 1990s. Science 304: 555-559

Häkkinen S, Rhines PB, Worthen DL (2011) Atmospheric blocking and Atlantic multidecadal ocean variability. Science 334:655-659

Hansen B, Østerhus S (2000) North Atlantic-Nordic Seas exchanges. Prog Oceanogr 45:109-208

Hansen B, Østerhus S, Turrell WR Jónsson S, Valdimarsson H, Hátún H, Olsen SM (2008) The inflow of Atlantic water, heat, and salt to the Nordic Seas across the Greenland-Scotland Ridge. In: Dickson RD, Meincke J, Rhines $P$ (eds) Arctic-Subarctic ocean fluxes: defining the role of the northern seas in climate. Springer, Dordrecht, p 15-43
Hátún H, Gaard E (2010) Marine climate, squid and pilot whales in the northeastern Atlantic. In: Bengtson SA, Buckland P, Enckell PH, Fossaa AM (eds) Dorete - her book. A tribute to Dorete Bloch and to Faroese nature. Annales Societatis Scientarium Færoensis Suplementum, Book 52. Faroe University Press, Tórshavn

Hátún H, Sandø AB, Drange H, Hansen B, Valdimarsson H (2005) Influence of the Atlantic subpolar gyre on the thermohaline circulation. Science 309:1841-1844

Hátún H, Payne MR, Beaugrand G, Reid PC and others (2009a) Large bio-geographical shifts in the north-eastern Atlantic Ocean: from the subpolar gyre, via plankton, to blue whiting and pilot whales. Prog Oceanogr 80: 149-162

> Hátún H, Payne MR, Jacobsen JA (2009b) The North Atlantic subpolar gyre regulates the spawning distribution of blue whiting (Micromesistius poutassou). Can J Fish Aquat Sci 66:759-770

Henson SA, Sarmiento JL, Dunne JP, Bopp L and others (2010) Detection of anthropogenic climate change in satellite records of ocean chlorophyll and productivity. Biogeosciences 7:621-640

- Hodson DLR, Sutton RT, Cassou C, Keenlyside N, Okumura Y, Zhou TJ (2010) Climate impacts of recent multidecadal changes in Atlantic Ocean sea surface temperature: a multimodel comparison. Clim Dyn 34:1041-1058

> Holliday NP (2003) Air-sea interaction and circulation changes in the northeast Atlantic. J Geophys Res C 108: 3259, doi: 10.1029/2002JC001344

Holliday NP, Hughes SL, Bacon S, Beszczynska-Möller A and others (2008) Reversal of the 1960s to 1990s freshening trend in the northeast North Atlantic and Nordic Seas. Geophys Res Lett 35:L03614, doi: 10.1029/2007GL 032675

Hovland EK, Hancke K, Alver MO, Drinkwater K and others (2013) Optical impact of an Emiliania huxleyi bloom in the frontal region of the Barents Sea. J Mar Syst (in press)

> Hutchins DA (2011) Oceanography: forecasting the rain ratio. Nature 476:41-42

Iglesias-Rodríguez MD, Brown CW, Doney SC, Kleypas J and others (2002) Representing key phytoplankton functional groups in ocean carbon cycle models: coccolithophorids. Global Biogeochem Cycles 16:1-20

Iglesias-Rodríguez MD, Halloran PR, Rickaby REM, Hall IR and others (2008) Phytoplankton calcification in a high$\mathrm{CO}_{2}$ world. Science 320:336-340

Ingvaldsen $R$, Loeng $H$ (2009) Physical oceanography. In: Sakshaug E, Johnsen G, Kovacs K (eds) Ecosystem Barents Sea. Tapir Academic Press, Trondheim, p 33-64

> Johannesen E, Ingvaldsen RB, Bogstad B, Dalpadado P and others (2012) Changes in Barents Sea ecosystem state, 1970-2009: climate fluctuations, human impact, and trophic interactions. ICES J Mar Sci 69:880-889

Kaplan A, Cane M, Kushnir Y, Clement A, Blumenthal M, Rajagopalan B (1998) Analyses of global sea surface temperature 1856-1991. J Geophys Res 103:18567-18589

Kerr RA (2000) A North Atlantic climate pacemaker for the centuries. Science 288:1984-1985

Knight JR, Folland CK, Scaife AA (2006) Climate impacts of the Atlantic multidecadal oscillation. Geophys Res Lett 33:L17706, doi: 10.1029/2006GL026242

Langehaug HR, Medhaug I, Eldevik T, Otterå OH (2012) Arctic/Atlantic exchanges via the Subpolar Gyre. J Clim 25:2421-2439

> Larsen KMH, Hátún H, Hansen B, Kristiansen R (2012) 
Atlantic water in the Faroe area: sources and variability. ICES J Mar Sci 69:802-808

Le Fouest V, Postlethwaite C, Morales Maqueda MA, Bélanger S, Babin M (2011) On the role of tides and strong wind events in promoting summer primary production in the Barents Sea. Cont Shelf Res 31:1869-1879

> Loeng H (1991) Features of the physical oceanographic conditions of the Barents Sea. Polar Res 10:5-18

> Loeng H, Drinkwater K (2007) An overview of the ecosystems of the Barents and Norwegian Seas and their response to climate variability. Deep-Sea Res II 54: 2478-2500

> Lohmann K, Drange H, Bentsen M (2009a) A possible mechanism for the strong weakening of the North Atlantic subpolar gyre in the mid-1990s. Geophys Res Lett 36: L15602, doi: 10.1029/2009GL039166

> Lohmann K, Drange H, Bentsen M (2009b) Response of the North Atlantic subpolar gyre to persistent North Atlantic oscillation like forcing. Clim Dyn 32:273-285

> Merico A, Tyrrell T, Brown CW, Groom SB, Miller PI (2003) Analysis of satellite imagery for Emiliania huxleyi blooms in the Bering Sea before 1997. Geophys Res Lett 30:1337, doi: 10.1029/2002GL016648

Merico A, Tyrrell T, Lessard EJ, Oguz T, Stabeno PJ, Zeeman SI, Whitledge TE (2004) Modelling phytoplankton succession on the Bering Sea shelf: role of climate influences and trophic interactions in generating Emiliania huxleyi blooms 1997-2000. Deep-Sea Res I 51:1803-1826

Moore TS, Dowell MD, Franz BA (2012) Detection of coccolithophore blooms in ocean color satellite imagery: a generalized approach for use with multiple sensors. Remote Sens Environ 117:249-263

Nanninga HJ, Tyrrell T (1996) Importance of light for the formation of algal blooms by Emiliania huxleyi. Mar Ecol Prog Ser 136:195-203

> Ottersen G, Stenseth NC (2001) Atlantic climate governs oceanographic and ecological variability in the Barents Sea. Limnol Oceanogr 46:1774-1780

Ottersen G, Adlandsvik B, Loeng H (2000) Predicting the temperature of the Barents Sea. Fish Oceanogr 9: 121-135

Panteleev GG, Nechaev DA, Ikeda M (2006) Reconstruction of summer Barents Sea circulation from climatological data. Atmos-ocean 44:111-132

Philippart CJM, Anadón R, Danovaro R, Dippner JW and others (2011) Impacts of climate change on European marine ecosystems: observations, expectations and indicators. J Exp Mar Biol Ecol 400:52-69

Preisendorfer RW (1988) Principal component analysis in meteorology and oceanography. Elsevier, New York, NY

Rey F (ed) (2004) Phytoplankton: the grass of the sea. Tapir Academic Press, Trondheim

Reynolds RW, Smith TM (1994) Improved global sea surface $\neq$ temperature analyses using optimum interpolation. J Clim 7:929-948

> Riebesell U, Kortzinger A, Oschlies A (2009) Sensitivities of marine carbon fluxes to ocean change. Proc Natl Acad Sci USA 106:20602-20609

Rost B, Riebesell U (2004) Coccolithophores and the biological pump: responses to environmental changes. In: Thierstein HR, Young JR (eds) Coccolithophores: from molecular processes to global impact. Springer-Verlag,
Berlin, p 99-125

Sakshaug E (2004) Primary and secondary production in the Arctic Seas. In: Stein R, MacDonald RW (eds) The organic carbon cycle in the Arctic Ocean. Springer-Verlag, Berlin, p 57-82

Sakshaug E, Johnsen G, Kovacs K (eds) (2009) Ecosystem Barents Sea. Tapir Academic Press, Trondheim

Sandø AB, Nilsen JEØ, Gao Y, Lohmann K (2010) Importance of heat transport and local air-sea heat fluxes for Barents Sea climate variability. J Geophys Res 115: C07013, doi: 10.1029/2009JC005884

Skagseth $\varnothing$, Furevik $T$, Ingvaldsen R, Loeng $H$, Mork K, Orvik K, Ozhigin V (2008) Volume and heat transport to the Arctic Ocean via the Norwegian and Barents Seas. In: Dickson R, Meincke J, Rhines P (eds) Arctic-Subarctic ocean fluxes. Springer, New York, NY, p 45-64

Skagseth O, Drinkwater KF, Terrile E (2011) Wind- and buoyancy-induced transport of the Norwegian Coastal Current in the Barents Sea. J Geophys Res C 116: C08007, doi: 10.1029/2011JC006996

Smyth TJ, Moore GF, Groom SB, Land PE, Tyrrell T (2002) Optical modeling and measurements of a coccolithophore bloom. Appl Opt 41:7679-7688

Smyth TJ, Tyrrell T, Tarrant B (2004) Time series of coccolithophore activity in the Barents Sea, from twenty years of satellite imagery. Geophys Res Lett 31:1-4, doi: 10.1029/ 2004GL019735

Sukhanova IN, Flint MV, Whitledge TE, Lessard EJ (2004) Coccolithophorids in the phytoplankton of the eastern Bering Sea after the anomalous bloom of 1997. Oceanology 44:665-678

Sunnanå K, Fossheim M, van der Meeren GI (2009) Forvaltningsplan Barentshavet-rapport fra overvåkingsgruppen 2009 (Norwegian). Fisken og havet 16. Norwegian Institute of Marine Research

Tyrrell T, Merico A (2004) Emiliania huxleyi: Bloom observations and the conditions that induce them. In: Thierstein HR, Young JR (eds) Coccolithophores: from molecular processes to global impact. Springer-Verlag, Berlin, p 75-97

Van Bleijswijk JDL, Kempers RS, Van der Wal P, Westbroek P, Egge JK, Lukk T (1994) Standing stocks of PIC, POC, PON and Emiliania Huxleyi coccospheres and liths in seawater enclosures with different phosphate loadings. Sarsia 79:307-317

Van der Wal P, Kempers RS, Veldhuis MJW (1995) Production and downward flux of organic matter and calcite in a North Sea bloom of the coccolithophore Emiliania huxleyi. Mar Ecol Prog Ser 126:247-265

- Vance TC, Schumacher JD, Stabeno PJ, Baier CT and others (1998) Aquamarine waters recorded for first time in Eastern Bering Sea. EOS Trans Am Geophys Union 79: 121-126

Visbeck M, Cullen H, Krahmann G, Naik N (1998) An ocean model's response to north Atlantic Oscillation-like wind forcing. Geophys Res Lett 25:4521-4524

Volent Z, Johnsen G, Hovland EK, Folkestad A, Olsen LM, Tangen K, Sorensen K (2011) Improved monitoring of phytoplankton bloom dynamics in a Norwegian fjord by integrating satellite data, pigment analysis, and Ferrybox data with a coastal observation network. J Appl Remote Sens $5 \mathrm{i}-\mathrm{ii}$ 